\title{
Pengaruh Artemisin dan Moringa terhadap Derajat Parasitemia, Kadar Malondialdehyde serta Histopatologi Otak Mencit Malaria
}

\section{Artemisin and Moringa Effect on Parasitaemia degree, Malondialdehyde Level and Brain Histopatology Malaria Modelled in Mice}

\author{
Tinny Endang $\mathrm{H}^{1}$, Loeki E Fitri', Resti Anggun $\mathrm{P}^{3}$ \\ ${ }^{1}$ Laboratorium Patologi Klinik Fakultas Kedokteran Universitas Brawijaya Malang \\ ${ }^{2}$ Laboratorium Mikrobiologi Fakultas Kedokteran Universitas Brawijaya Malang \\ ${ }^{3}$ Program Studi Magister IImu Biomedik Fakultas Kedokteran Universitas Brawijaya Malang
}

\begin{abstract}
ABSTRAK
Salah satu bentuk infeksi malaria berat adalah malaria serebral ditandai dengan respon inflamasi berlebih dan peningkatan jumlah pembuluh darah di jaringan otak sehingga menyebabkan terbentuknya radikal bebas secara berlebihan. Ekstrak daun Kelor (Moringa oleifera) berpotensi sebagai antioksidan dan antiinflamasi yang diharapkan dapat bekerja sebagai terapi adjuvant untuk kombinasi dengan artemisin. Penelitian ini bertujuan untuk menguji pengaruh kombinasi Artemisin dan ekstrak daun Moringa oleifera terhadap derajat parasitemia, kadar MDA dan gambaran histopatologi pada jaringan otak mencit yang diinfeksi P.berghei. Penelitian ini merupakan True Experimental Design. Sampel penelitian yang digunakan adalah mencit galur BALB/c. Bedasarkan hasil analisis Post Hoc pada hari ke-3 dan ke-7, terdapat perbedaan rerata derajat parasitemia, kadar MDA, dan jumlah pembuluh darah di jaringan otak yang bermakna antara kontrol positif dan semua perlakuan $(p<0,05)$. Pada kelompok yang diterapi Artemisin, didapatkan derajat parasitemia yang lebih rendah dibandingkan dengan kontrol positif $(p<0,05)$, namun lebih tinggi dibandingkan dengan kelompok kombinasi $(p<0,05)$. Rerata kadar MDA turun signifikan pada hari ke 7 terutama pada kelompok kombinasi dosis tertinggi $(p=0,000)$ dibandingkan dengan hari ke 3. Pada pengamatan jumlah pembuluh darah di jaringan otak mencit didapatkan bahwa pada hari ke 7 terjadi penurunan signifikan pada jumlah pembuluh darah di kelompok kombinasi dibandingkan kelompok Artemisin. Dapat disimpulkan kombinasi Artemisin dan ekstrak daun Moringa oleifera lebih baik menurunkan derajat parasitemia, kadar MDA dan jumlah pembuluh darah di jaringan otak mencit dibandingkan dengan terapi artemisin saja.
\end{abstract}

Kata Kunci: Derajat parasitemia, histopatologi otak, malaria, Malondialdehyde

\begin{abstract}
Cerebral malaria is the severe form of malaria disease which is characterized by excessive inflammatory response and increased number of blood vessel in the brain tissues. inflammation provide free radicals that deteriorate patients condition. Moringa oleifera leaf extract which accupies antioxidant, anti-inflammation and imunostimulant effects is expected to improve artemisin effect on malaria. The purpose of the study is to test the effect of Artemisin and Moringa leaves (Moringa Olifera) combination towards the degree of parasitaemia, MDA level and brain tissue histopatological image of mice with P beghei infection. The method used is True Experimental Design. The samples are BALB/C mice. Based on Post Hoc analysis on the $3^{\text {rd }}$ and $7^{\text {th }}$ day of observation, there was a significant difference in the mean of the degree of parasitaemia, MDA level and number of blood vessel in the brain between positive control group and all treatment groups $(p<0,05)$. In the group that was given Artemisin only, the degree of parasitaemia was lower than that of control positive $(p<0,05)$, but higher than the groups being given the combination. The MDA level decreased significantly on the $7^{\text {th }}$ day of observation especially in the highest combination group $(p=0,000)$ more than the $3^{\text {rd }}$ day of observation. Histopatological image of brain tissues revealed significant decreased number of blood vessel in combination group compared to those in Artemisin group on the seventh day of observation. The combination of Artemisin and Moringa leaf extract works more effectively than Artemisin treatment to decrease the degree of parasitaemia, MDA level and the number of blood vessels.
\end{abstract}

Keywords: Histopatological brain, malaria, Malondialdehyde, the degree of parasitaemia

Korespondensi: Resti Anggun P. Program Studi Magister Ilmu Biomedik Fakultas Kedokteran Universitas Brawijaya Malang, Jl. Veteran Malang65145 Tel.(0341)575790Email:resti_pertiwi@yahoo.com 


\section{PENDAHULUAN}

Malaria merupakan masalah kesehatan global. Di Indonesia, mortalitas akibat malaria serebral sekitar 20$50 \%$ dari seluruh kejadian malaria. Saat ini terdapat lima spesies Plasmodium yang diketahui dapat menginfeksi manusia, yaitu Plasmodium $(P)$. falciparum, $P$. vivax, $P$. ovale, P. malariae, dan P. knowlesi. Plasmodium falciparum diketahui sebagai spesies yang berperan pada kasus malaria berat, salah satunya melalui komplikasi malaria serebral (1).

Patogenesis dasar terjadinya malaria serebral melalui proses cytoadherence, rosseting, autoagglutination dan sequestration. Sequestration pada eritrosit yang terinfeksi di dalam pembuluh darah merupakan patogenesis yang esensial dari malaria serebral. Selain itu, radikal bebas yang terbentuk selama infeksi malaria dapat menyebabkan kerusakan jaringan (2). Jaringan yang paling sering mengalami kerusakan pada malaria adalah hati dan otak. Pada kondisi malaria serebral gambaran histopatologi otak pada mencit yang diinfeksi Plasmodium falciparum menyebabkan kondisi patologis dan menunjukkan kerusakan terutama pada kondisi neuron, aktivasi mikroglia dan adanya peningkatan jumlah pembuluh darah (3).

Artemisin dan derivatnya, dihidroartemisinin, artesunate, dan artemeter, merupakan suatu endoperoksida (sesquiterpene lactone endoperoxide) yang memiliki kemampuan sebagai antimalaria yang poten dan bekerja cepat $(4,5)$. Obat ini bekerja dengan menghambat enzim ATPase dan menghasilkan radikal bebas untuk mengeliminasi parasit penyebab malaria sehingga penggunaan obat ini dapat menyebabkan penumpukan radikal bebas dalam tubuh $(6,7)$. Artemisin saat ini digunakan untuk pengobatan malaria berat (8) dan penggunaan obat ini dianjurkan dalam bentuk kombinasi yang dikenal dengan artemisin-based combination therapies (ACT) (1). Suatu obat antimalarial dapat disebut sebagai kombinasi apabila mempunyai kerja yang sama sebagai skizontosida darah juga (9). Artemisin combination therapies mempunyai banyak manfaat karena dapat mencegah terjadinya resistensi $(1,10)$, serta mengurangi risiko terjadinya rekrudensi (11). Pada suatu studi dikatakan parasit Plasmodium falcifarum mempunyai kecenderungan menjadi resisten terhadap obat antimalaria dibandingkan spesies yang lain (12). Resistensi terhadap artemisinin tersebut dapat dipastikan jika terjadi kegagalan terapi artemisin-based monotherapy secara oral, yang dibuktikan dengan masih terdeteksinya parasit pada hari ke-7, atau terdapatnya parasit pada hari ke-3 dan terjadi rekrudesensi dalam waktu 28 atau 42 hari (tergantung obat yang digunakan) (1).

Oleh karena itu diperlukan suatu zat yang bersifat skizontisida dan antioksidan sebagai terapi kombinasi serta suportif yang dapat mengatasi penumpukan radikal bebas yang terbentuk selama infeksi malaria dan terapi artemisin. Fitri, et al,. (2008) melaporkan penurunan derajat parasitemia dan Malondialdehyde (MDA) pada otak dan paru mencit yang diinfeksi Plasmodium berghei dan diberikan kombinasi artemisin dan $\mathrm{N}$-acetylcysteine (NAC) yang merupakan antioksidan (13).

Moringa oleifera merupakan salah satu tanaman tradisional yang banyak digunakan untuk pengobatan berbagai macam penyakit, salah satunya adalah malaria. Kandungan total fenol dalam ekstrak Moringa oleifera adalah $118 \mathrm{mg} / \mathrm{g}$, merupakan kadar yang cukup tinggi bila dibandingkan dengan tanaman lain yang juga mengandung fenol (14). Berdasarkan penelitian secara in vitro, Moringa oleifera memiliki aktivitas antioksidan, antiinflamasi dan skizontisidal pada $P$ falciparum $(15,16)$. Penelitian ini dilakukan untuk mengetahui pengaruh penggunaan terapi Artemisin yang dikombinasikan dengan ekstrak Moringa oleifera sebagai antioksidan dan antimalaria terhadap penurunan derajat parasitemia dan stres oksidatif menggunakan MDA sebagai parameter produk aktif dari radikal bebas hasil dari infeksi malaria serta melihat adanya perubahan histopatologi otak mencit model malaria yang diinfeksi dengan Plasmodium berghei ANKA. Penelitian ini telah mendapatkan persetujuan dari Komisi Etik Fakultas Kedokteran Universitas Brawijaya dengan nomor surat persetujuan etik 103/EC/KEPKS2/02/2013.

\section{METODE}

\section{Desain Penelitian}

Penelitian ini merupakan penelitian eksperimental laboratorik rancangan post test only controlled group design, randomised controlled trial (RCT), dilakukan pada bulan April- Juni 2012. Penelitian ini memakai parasit Plasmodium berghei yang didapatkan dari Laboratorium Biomedik FK Universitas Brawijaya Malang. Pembagian kelompok sampel penelitian disajikan pada Tabel 1.

Tabel 1. Pembagian kelompok sampel penelitian

\begin{tabular}{ll}
\hline Kelompok sampel & Perlakuan pada masing-masing kelompok \\
\hline Kontrol negative & Kelompok mencit yang tidak diinfeksi \\
& P.berghei dan tidak diberi pengobatan
\end{tabular}

Kontrol positif

Kelompok mencit yang diinfeksi P.berghei dan tidak diberi pengobatan

Artemisin

Kelompok mencit yang diinfeksi P.berghei dan diberi artemisin dosis tunggal $0,12 \mathrm{mg} /$ hari

DK1 (kombinasi dosis 1) Kelompok mencit yang diinfeksi P.berghei dan diberi artemisin dosis $0,12 \mathrm{mg} /$ hari dan ekstrak Moringa oleifera $3,75 \mathrm{mg} /$ hari

DK2 (kombinasi dosis 2) Kelompok mencit yang diinfeksi P.berghei dan diberi artemisin dosis $0,12 \mathrm{mg} /$ hari dan ekstrak Moringa oleifera $7,5 \mathrm{mg} /$ hari

DK3 (kombinasi dosis 3) Kelompok mencit yang diinfeksi P.berghei dan diberi artemisin dosis $0,12 \mathrm{mg} /$ hari dan ekstrak Moringa oleifera $15 \mathrm{mg} /$ hari

\section{Hewan Coba}

Hewan coba yang dipakai adalah mencit model malaria (mencit galur BALB/c) jantan dengan berat 20-40gram dari 
Pusvetma Surabaya. Hewan ini di tempatkan di dalam kandang berukuran $30 \times 30 \mathrm{~cm}$ yang berisi 5 ekor mencit di setiap kandang, hewan coba ini dipelihara di Laboratorium Parasitologi.

\section{Persiapan dan Inokulasi P.berghei}

Plasmodium berghei didapatkan dari Laboratorium Biomedik Universitas Brawijaya. Eritrosit mencit yang terinfeksi P.berghei dan tersimpan dalam tabung nitrogen cair dicairkan, dan secara berturut-turut ditambah dengan $\mathrm{NaCl} 12 \%$ dan $\mathrm{NaCl} 1,6 \%$. Isolat tersebut selanjutnya diinkubasikan selama 5 menit. Pelet yang diperoleh dilarutkan dalam medium RPMI untuk inokulasi $10^{7}$ parasit dalam $0,2 \mathrm{ml}$ darah untuk setiap mencit secara intra-peritoneal (12). Derajat parasitemia dinilai berdasarkan persentase eritrosit yang terinfeksi Plasmodium berghei dalam 1000 eritrosit (dihitung dengan hand counter) pada hapusan darah tipis (thin smear) yang dipulas dengan pewarnaan Giemsa dan diamati dengan pembesaran 40x (17). Mencit dikatakan sudah mengalami malaria berat bila didapatkan derajat parasitemia $>1-5 \%$ pada hapusan darah .

\section{Ekstraksi Daun Moringa oleifera}

Daun Moringa oleifera yang digunakan merupakan varietas NTT. Ekstraksi dilakukan melalui tiga proses, yaitu pengeringan, ekstraksi dan evaporasi. Pada proses ekstraksi daun kelor dihaluskan dan ditimbang sampai didapatkan berat 100 gram. Sampel tersebut selanjutkan direndam metanol selama satu malam. Proses yang terakhir adalah evaporasi, bagian teratas dari sampel yang telah direndam diambil dan ditempatkan ke dalam evaporator dengan suhu $90^{\circ} \mathrm{C}$. Bahan aktif yang diekstrak dari proses tersebut ditempatkan ke dalam gelas penampung dan dikirim ke Laboratorium Penelitian dan Pengujian Terpadu (LPPT) Universitas Gadjah Mada dan dilakukan pemeriksaan kromatografi lapis tipis untuk mengetahui kandungan fenol dalam ekstrak daun Moringa oleifera. Hasil menunjukkan total fenol ekivalen asam galat sebesar $15,23 \%$ (14).

\section{Persiapan Sampel Otak Mencit}

Waktu pembedahan mencit pada setiap kelompok mencit, dilakukan pada hari ke-3 dan hari ke-7 setelah pemberian perlakuan (artemisin dan kombinasi artemisin daun Moringa oleifera). Pada setiap kelompok hari perlakuan tiga ekor mencit dikorbankan dan jaringan otaknya segera diambil. Hemisfer otak sisi kiri ditempatkan pada tabung berisi larutan formalin $10 \%$ untuk dilakukan pemeriksaan histopatologi dan hemisfer otak sisi kanan di letakan pada alumunium foil untuk selanjutnya dilakukan pemeriksaan MDA.

\section{Pemeriksaan MDA}

Kadar MDA dalam jaringan otak diukur dengan metode spektrofotometri pada setiap kelompok mencit. Langkah awal yang dilakukan adalah jaringan otak dibersihkan dengan $0,9 \% \mathrm{NaCl}$ dan ditimbang untuk menentukan perbandingan dengan buffer PBS ( 1 gram jaringan per 10 $\mathrm{ml}$ buffer). Sebanyak $10 \mu \mathrm{L}$ 0,5 M BHT dalam acetonitrile ditambahkan per $1 \mathrm{ml}$ homogenat jaringan. Homogenat disentrifus $3000 \mathrm{~g}$ pada suhu $4^{\circ} \mathrm{C}$ selama 10 menit. Sebanyak $200 \mu \mathrm{L}$ supernatan yang diperoleh dimasukkan ke dalam tabung gelas atau tabung mikrosentrifus polipropilen bersama dengan $650 \mu \mathrm{L}$ reagen $\mathrm{R} 1$ dan divortex. Kemudian ditambahkan $150 \mu \mathrm{L} \mathrm{HCl}$ terkonsentrasi (12N) lalu dicampur dan ditutup. Inkubasi dilakukan pada suhu $45^{\circ} \mathrm{C}$ selama 60 menit. Sampel kemudian disentrifus $15.000 \mathrm{~g}$ selama 10 menit untuk mendapatkan supernatan yang jernih dan diukur pada panjang gelombang $586 \mathrm{~nm}$ (18).

\section{Pewarnaan Hematoksilin Eosin Pada Jaringan Otak}

Slide yang akan diwarnai diletakkan di rak khusus pengecatan. Langkah pertama yang dilakukan adalah pemberian Harris Hematoksilin selama 15 menit, selanjutkan cuci dengan air mengalir selama 15 menit. Sediaan dicelupkan pada alkohol asam 1\% sebanyak 2-5 celupan lalu setelahnya celupkan ke dalam ammonia air. Dilakukan counter staining selama $15-20$ detik. Tahapan selanjutnya adalah proses dehidrasi pada alkohol bertingkat selama 3 menit (alkohol 70\%, 80\%, 96\% dan absolut). Proses penjernihan sediaan dilakukan dengan pemberian xylol selama 5 menit. Tahapan akhir dari proses pewarnaan ini adalah dengan membiarkan slide sediaan kering pada suhu ruang. Sediaan HE dapat diamati di bawah mikroskop $(19,20)$.

\section{Analisis Data}

Analisis data dikerjakan dengan menggunakan SPSS 17 dengan uji $t$-independent dan uji Mann Whitney digunakan untuk menganalisis perbedaan antar kelompok perlakuan pada pangamatan hari ke-3 dan ke-7, uji One Way ANOVA dan uji Post Hoc Tukey. Uji ini digunakan untuk mendapatkan nilai rata-rata dari keenam populasi memang berbeda. Hasil uji bermakna jika nilai $p<0,05$.

\section{HASIL}

\section{Derajat Parasitemia}

Data menunjukkan terdapat perbedaan rerata derajat parasitemia yang bermakna antara hari ke-3 dan hari ke-7 pada kelompok kontrol positif $(p=0,031)$, Artemisin $(p=0,021)$, DK2 $(p=0,004)$ dan DK3 $(p=0,000)$ namun tidak didapatkan perbedaan yang bermakna pada kelompok DK1 $(p=0,05)$. Hasil uji One Way ANOVA untuk derajat parasitemia diantara berbagai kelompok pada hari ke-3 menunjukkan perbedaan bermakna $(p=0,000)$. Analisis post hoc Tukey menunjukkan perbedaan rerata derajat parasitemia yang bermakna secara statistik antara kelompok kontrol positif dan artemisin $(p=0,007)$, kontrol positif dan DK1 $(p=0,000)$, kontrol positif dan DK2 $(p=0,000)$, dan kontrol positif dan DK3 $(p=0,000)$, artemisin dan DK2 $(p=0,013)$, artemisin dan DK3 $(p=0,002)$. Tidak didapatkan perbedaan yang bermakna antara kelompok Artemisin dan DK2 ( $p=0,117)$, DK1 dan DK2 ( $p=0,779)$, DK1 dan DK3 $(0,241)$ dan pada kelompok DK2 dan DK3 $(p=0,886)$ (Gambar 1). Hasil tersebut menunjukkan pemberian artemisin saja maupun kombinasi dengan moringa oleifera sudah memberika derajat parasitemia yang lebih rendah dibandingkan kondisi infeksi (kontrol positif). Diantara ketiga dosis kombinasi, hanya dosis 7.5 $\mathrm{mg} /$ hari dan $15 \mathrm{mg} /$ hari yang memberikan derajat parasitemia lebih rendah bila dibandingkan pemberian artemisin saja, sedangkan dosis 3.75 tidak

Uji Mann Whitney (Gambar 1) dilakukan untuk derajat parasitemia berbagai kelompok pada hari ke-7 menunjukkan perbedaan rerata derajat parasitemia yang bermakna pada semua kelompok perlakuan kecuali antar kelompok DK1 dan DK2 $(p=0,072)$. Berbeda dengan hari ketiga pemberian kombinasi Moringa oleifera pada semua dosis termasuk dosis terendah $3,75 \mathrm{mg} /$ hari selama 7 hari 
efektif menurunkan derajat parasitemia dibandingkan dengan pemberian artemisin saja. Berdasarkan data tersebut dosis kombinasi artemisin dan ekstrak daun Moringa oleifera yang bisa dipertimbangkan untuk digunakan dalam pengobatan infeksi malaria adalah artemisin $0,12 \mathrm{mg} /$ hari dan Moringa oifeira $7,5 \mathrm{mg} /$ hari atau $15 \mathrm{mg} /$ hari.

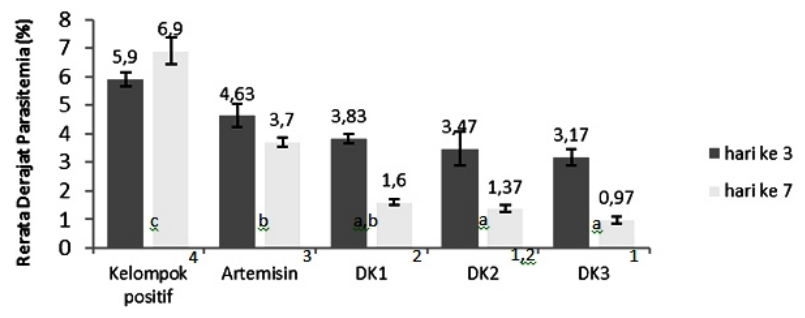

Gambar 1. Grafik efektivitas kombinasi artemisin dan ekstrak daun Moringa oleifera dalam menurunkan derajat parasitemia pada pengamatan hari ke-3 dan ke-7

Keterangan: Notasi $\mathrm{a}, \mathrm{b}$ dan c menunjukkan perbedaan bermakna untuk kelompok perlakuan hari ke 3 . Notasi $1,2,3$, dan 4 menunjukkan perbedaan bermakna untuk kelo mpok perlakuan hari ke-7

\section{Kadar MDA di Jaringan Otak}

Bedasarkan hasil pemeriksaan kadar MDA pada kelompok perlakuan menunjukkan terdapat perbedaan rerata kadar MDA yang bermakna antara hari ke-3 dan hari ke-7 pada kelompok DK2 $(p=0,006)$ dan DK3 $(p=0,000)$. Tidak didapatkan perbedaan yang bermakna pada kelompok kontrol negatif $(p=0,576)$, kontrol positif $(p=0,140)$, dan DK1 $(p=0,819)$. Uji One Way ANOVA untuk kadar MDA diantara berbagai kelompok perlakuan pada hari ke-3 menunjukkan perbedaan bermakna $(p=0,000)$. Analisis post hoc Tukey menunjukkan perbedaan rerata kadar MDA yang bermakna antara kelompok kontrol negatif dan positif $(p=0,000)$, kontrol negatif dan artemisin $(p=0,000)$, kontrol negatif dan DK1 $(p=0,006)$, kontrol negatif dan DK2 $(p=0,000)$, kontrol negatif dan DK3 $(p=0,003)$, kontrol positif dan Artemisin $(p=0,001)$, kontrol positif dan DK1 $(p=0,000)$, kontrol positif dan DK2 $(p=0,000)$, dan kontrol positif dan DK3 $(p=0,000)$, Artemisin dan DK1 $(p=0,001)$, artemisin dan DK2 $(p=0,011)$, dan Artemisin dan DK3 $(p=0,001)$. Tidak didapatkan perbedaan yang bermakna antara kelompok DK1 dan DK2 $(p=0,454)$, DK1 dan DK3 $(p=0,990)$ dan pada kelompok DK2 dan DK3 $(p=0,778)$. Hal ini menunjukkan bahwa ketiga dosis kombinasi tidak mempunyai perbedaan penurunan MDA namun memberikan penurunan lebih rendah bila dibandingkan artemisin saja.

Uji Post Hoc Tukey untuk kadar MDA berbagai kelompok pada hari ke-7 menunjukkan perbedaan rerata kadar MDA yang bermakna pada semua kelompok perlakuan kecuali pada kelompok kontrol negatif dan DK2 $(p=0,295)$, kontrol negatif dan DK3 $(p=0,992)$, DK1 dan DK2 $(p=0,094)$ dan DK2 dan DK3 $(p=0,058)$. Pemeriksaan kadar MDA pada pengamatan hari ke 7 menunjukkan bahwa pemberian kombinasi artemisin dan daun Moringa oleifera dosis $7,5 \mathrm{mg} /$ hari dan $15 \mathrm{mg} /$ hari memiliki efektivitas lebih baik menurunkan kadar MDA (19,8 \% dan 20,6 \%) dibandingkan pemberian monoterapi artemisin $0,12 \mathrm{mg} /$ hari $(7 \%)$.

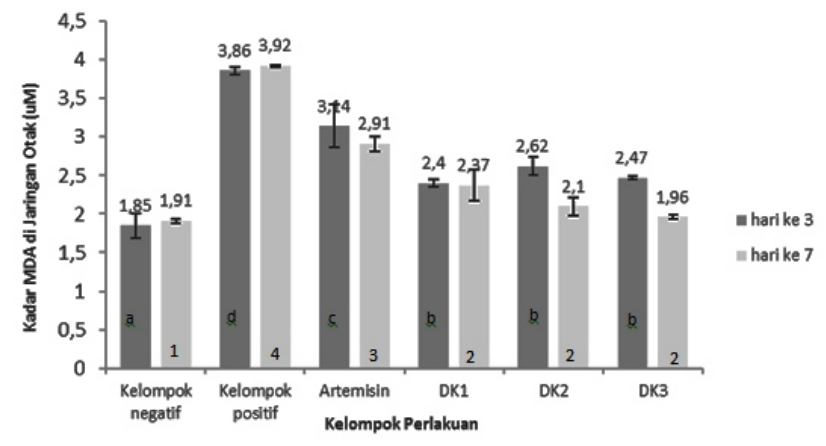

Gambar 2. Grafik efektivitas kombinasi artemisin dan ekstrak daun Moringa oleifera dalam menurunkan kadar MDA di jaringan otak pada pengamatan hari ke 3 dan ke-7

Keterangan: Notasi a,b dan c menunjukkan perbedaan bermakna untuk kelompok perlakuan hari ke-3. Notasi 1, 2, 3, dan 4 menunjukkan perbedaan bermakna untuk kelompok perlakuan hari ke-7.

\section{Jumlah Pembuluh Darah di Jaringan Otak}

Berdasarkan hasil pengamatan jumlah pembuluh darah per 10 lapang pandang di jaringan otak mencit kelompok perlakuan hari ke 3 didapatkan nilai rerata yang paling kecil pada kelompok kontrol negatif $31,66 \pm 1,52$ dan paling tinggi pada kontrol positif $56,33 \pm 0,57$ diikuti artemisin $53,33 \pm 0,57$, DK1 49,33 $\pm 1,15$, DK2 44,33 $\pm 1,52$, dan DK3 $43,66 \pm 0,57$. Pada pengamatan hari ke 7 didapatkan hasil jumlah pembuluh darah per 10 lapang pandang pada kelompok negatif $32,33 \pm 2,08$, positif $64,33 \pm 1,52$, artemisin $52 \pm 1,73$, DK1 44,66 $\pm 1,15$, DK2 38 $\pm 2,0$, dan DK3 $36,33 \pm 1,52$.

Haasil uji t-test menunjukkan terdapat perbedaan jumlah pembuluh darah yang bermakna antara hari ke-3 dan hari ke-7 pada kelompok kontrol positif $(p=0,046)$, DK1 $(p=0,043)$, DK2 $(p=0,046)$ dan DK3 $(p=0,046)$. Tidak didapatkan perbedaan yang bermakna pada kelompok kontrol negatif $(p=0,678)$ dan artemisin $(p=0,197)$. Analisis post hoc Mann Whitney menunjukkan perbedaan rerata jumlah pembuluh darah yang bermakna antara kelompok kontrol negatif dan positif $(p=0,046)$, kontrol negatif dan artemisin $(p=0,046)$, kontrol negatif dan DK1 $(p=0,046)$, kontrol negatif dan DK3 $(p=0,046)$, kontrol positif dan artemisin $(p=0,043)$, kontrol positif dan DK1 $(p=0,043)$, kontrol positif dan DK2 ( $p=0,046)$, dan kontrol positif dan DK3 $(p=0,043)$, artemisin dan DK1 $(p=0,043)$, Artemisin dan DK2 $(p=0,046)$, Artemisin dan DK3 $(p=0,043)$. Tidak didapatkan perbedaan yang bermakna antara kelompok DK2 dan DK3 ( $p=0,637)$.

Uji Mann Whitney untuk jumlah pembuluh darah berbagai kelompok pada hari ke-7 menunjukkan perbedaan yang bermakna pada kelompok perlakuan kontrol negatif dan artemisin $(p=0,046)$, kontrol negatif dan DK1 $(p=0,046)$, kontrol positif dan artemisin $(p=0,046)$, kontrol positif dan DK1 $(p=0,046)$, artemisin dan DK1 $(p=0,043)$, artemisin dan DK2 $(p=0,046)$, artemisin dan DK3 $(p=0,046)$, DK1 dan DK2 $(p=0,046)$ dan pada kelompok DK1 dan DK3 $(p=0,046)$. Pada Gambar 3 menunjukkan bahwa pemakaian kombinasi artemisin dengan penambahan ekstrak daun Moringa oleifera dosis $3,75 \mathrm{mg} /$ hari $(9,4 \%)$ selama 7 hari sudah dapat menurunkan jumlah pembuluh darah di jaringan otak lebih baik dibanding dengan pemberian artemisin saja $(2,4 \%)$, demikian juga pemberian selama tiga hari. Dosis optimum adalah pada kombinasi 
$7,5 \mathrm{mg} /$ hari karena tidak didapatkan perbedaan dengan peningkatan dosis menjadi $15 \mathrm{mg} /$ hari.

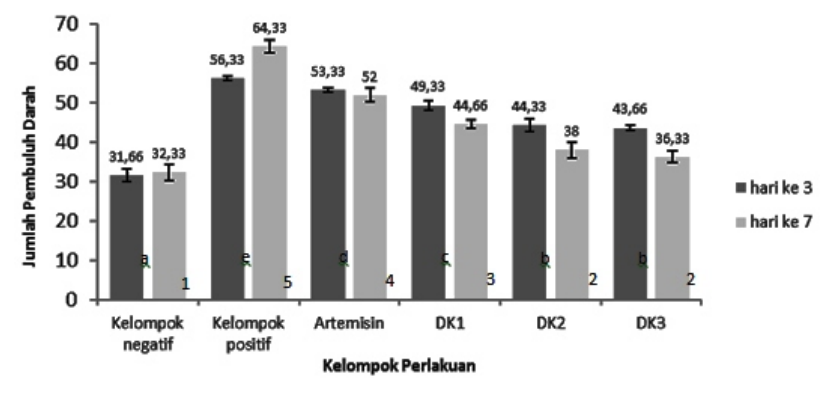

Gambar 3. Grafik efektivitas kombinasi artemisin dan ekstrak daun Moringa oleifera dalam menurunkan jumlah pembuluh darah di jaringan otak pada pengamatan hari ke 3 dan ke-7

Keterangan: Notasi a,b dan c menunjukkan perbedaan bermakna untuk kelompok perlakuan hari ke-3. Notasi 1, 2, 3, dan 4 menunjukkan perbedaan bermakna untuk kelompok perlakuan hari ke-7.

\section{DISKUSI}

Radikal bebas pada infeksi malaria dapat dihubungkan dengan patogenesis malaria berat, terutama pada proses sekuestrasi sehingga menimbulkan suatu komplikasi. Protein glycosilphosphatidylinositol (GPI) yang dihasilkan oleh lisis nya eritrosit terinfeksi Plasmodium berghei mampu merangsang aktivitas makrofag dan menghasilkan sitokin proinflamasi (4). Pada kasus malaria serebral, sitokin tersebut dan GPI akan menginduksi respon imun di jaringan otak dengan akibat dihasilkannya sitokin proinflamasi di dalam jaringan otak (20) sehingga akan mengalami iskemia dan meginduksi respon inflamasi yang berlebihan di jaringan otak (2). Proses inflamasi yang berlebihan dalam jaringan otak dimediasi oleh produksi sitokin dan radikal bebas (21). Penggunaan antioksidan sebagai terapi suportif yang dikombinasikan dengan antimalaria artemisin dianggap penting untuk mempercepat proses kesembuhan serta mengurangi kerusakan jaringan normal yang lebih berat akibat pembentukan radikal bebas yang berlebihan $(22,23)$.

Hasil penelitian menunjukkan derajat parasitemia mengalami penurunan yang bermakna secara statistik pada penggunaan kombinasi artemisin dan ekstrak daun Moringa oleifera bila dibandingkan artemisin saja. Hal ini menunjukkan kemungkinan daun Moringa oleifera dapat berguna sebagai anti malarial selaras dengan penelitian in vitro Okechukwu (2013) bahwa ekstrak daun Moringa oleifera bersifat skizontisida (16). Hasil pengamatan hari ke 3 pada kelompok kombinasi artemisin dan ekstrak daun Moringa oleifera berbagai dosis memberikan hasil lebih baik dibandingkan dengan artemisin saja sebagai obat standar. Dari ketiga dosis kombinasi artemisin dan ekstrak daun Moringa oleifera tersebut, kelompok dengan dosis kombinasi $7.5 \mathrm{mg} /$ hari dan $15 \mathrm{mg} /$ hari yang paling baik dalam menurunkan rerata derajat parasitemia pada pengamatan hari ke 3 . Pada pengamatan hari ke 7 menunjukkan pemberian kombinasi artemisin 0,12 $\mathrm{mg} /$ hari ditambah dengan ekstrak daun Moringa oleifera dosis $15 \mathrm{mg} /$ hari (DK3 paling efektif menurunkan derajat parasitemia dibandingkan kelompok perlakuan lainnya dengan penurunan derajat parasitemia 69,4\%. Pada penelitian ini didapatkan penurunan derajat parasitemia tidak mencapai $0 \%$, hal tersebut kemungkinan terjadi karena pemberian dosis terapi pada penelitian ini menggunakan hasil konversi dari dosis manusia, sehingga tidak sesuai dosis sesungguhnya pada mencit sehingga memungkinkan adanya perbedaan efektivitas obat.

Malondialdehyde merupakan senyawa dialdehida atau berkarbon tiga yang reaktif merupakan produk akhir peroksidasi lipid di dalam membran sel. MDA dalam material hayati terdapat dalam bentuk bebas atau membentuk ikatan kompleks dengan unsur lainnya di dalam jaringan. Mekanisme pembentukan MDA melalui peroksidasi lipid diawali dengan penghilangan atom hidrogen $(\mathrm{H})$ dari molekul lipid tak jenuh rantai panjang oleh gugus radikal hidroksil $\left({ }^{*} \mathrm{OH}\right)$, sehingga lipid bersifat radikal. Kemudian radikal lipid ini bereaksi dengan atom oksigen $\left(\mathrm{O}_{2}\right)$ membentuk radikal peroksil (*OO), yang selanjutnya menghasilkan MDA (dengan ikatan tak jenuh lebih dari tiga). Radikal bebas lebih berbahaya dibandingkan dengan oksidan yang bukan radikal bebas. Wresdiati (2003) menjelaskan bahwa tingginya kadar MDA dipengaruhi oleh kadar peroksidasi lipid yang secara tidak langsung juga menunjukkan tingginya jumlah radikal bebas $(24,25)$.

Hasil penelitian menunjukkan rerata kadar MDA di jaringan otak mencit pada kelompok positif pada hari ke-3 (3,86 uM) dan semakin meningkat bermakna pada pengamatan hari ke-7 (3,92 uM) dibandingkan dengan kelompok kontrol negatif ( 1,85 uM dan 2,91 uM). Hal ini sesuai dengan laporan Malaguanera dan Musumeci (2002) yang menyatakan bahwa selama infeksi malaria terjadi gangguan aktivasi dan fungsi makrofag sehingga aktivitas fagositosis parasit terganggu dan tidak mampu menghasilkan radikal oksidan dan NO yang merupakan parasite killing, sehingga terjadi peningkatan radikal bebas (23).

Penelitian ini membuktikan bahwa pemberian kombinasi Artemisin dosis 0,12 $\mathrm{mg} /$ hari dengan ekstrak daun Moringa oleifera selama 7 hari lebih efektif menurunkan kadar MDA di jaringan otak (dosis kombinasi19,8\% dan 20,6\%). Semakin tinggi dosis kombinasi ekstrak daun Kelor yang diberikan, semakin rendah juga kadar MDA yang didapatkan. Tingginya kadar MDA pada penelitian ini sesuai dengan penelitian yang dilakukan oleh Raza et al., 2013 yang menemukan bahwa kadar MDA yang tinggi pada infeksi malaria sebanding dengan tinggi nya derajat parasitemia (26). Odulade et al., 2014 juga menemukan adanya penurunan kadar MDA setelah pemberian Moringa oleifera pada infeksi malaria (28). Hasil penelitian ini membuktikan bahwa daun Moringa oleifera dapat dikembangkan sebagai obat tambahan pada infeksi malaria, sejalan dengan penelitian sebelumnya yang membuktikan efek antioksidan daun Moringa oleifera $(14,27)$.

Penelitian Deininger et al., 2003 pada malaria serebral, aktivasi mikrovaskular dan disfungsi blood brain barrier menunjukkan basis patofisiologis kelainan neurologis pada beberapa pasien. Pada kondisi malaria serebral gambaran histopatologi otak pada mencit yang terinfeksi Plasmodium berghei melalui mekanisme imun, mekanik dan radikal bebas infeksi Plasmodium falciparum menyebabkan kondisi patologis dan menunjukkan kerusakan terutama pada kondisi neuron, aktivasi mikroglia dan adanya peningkatan pembuluh darah $(6,29)$.

Penelitian ini hanya menggambarkan profil jumlah pembuluh darah di jaringan otak mencit yang diinfeksi 
Plasmodium berghei. Hasil menunjukkan pemberian artemisin, maupun dengan kombinasi Moringa oleifera memiliki efektivitas yang sama dalam menurunkan jumlah pembuluh darah pada pengamatan histopatologi jaringan otak mencit. Pemberian artemisin monoterapi dosis 0,12 $\mathrm{mg} /$ hari selama 3 hari sudah cukup efektif untuk menurunkan jumlah pembuluh darah, dan pemberian artemisin saja sampai dengan hari ke-7 mampu menurunkan jumlah pembuluh darah di jaringan otak pada infeksi malaria walaupun tanpa penambahan ekstrak daun Moringa oleifera. Hal ini kemungkinan menunjukan adanya perbaikan dari kondisi infeksi malaria setelah penggunaan terapi kombinasi selama 7 hari. Dalam penelitian Octo, 2009 tentang gambaran histopatologi otak mencit malaria terhadap penggunaan antioksidan juga menyatakan adanya perbaikan kondisi perdarahan di otak mencit yang telah diinokulasi

\section{DAFTAR PUSTAKA}

1. World Health Organization. World Malaria Report: 2012. Switzerland: WHO Press: 2012; pp. 1-2, 39-44.

2. Idro R, Jenkins NE and Newton NE. Pathogenesis Clinical Features, and Neurological Outcome of Cerebral Malaria. The Lancet Neurology. 2005; 4(12): 827-840.

3. Jennings VM, Lal AA, and Hunters RL. Evidence for Multiple Pathologic and Protective Mechanisms of Murine Cerebral Malaria. Infection and Immunity. 1998; 66(12): 5972-5979

4. Brown GD. The Biosynthesis of Artemisinin (Qinghaosu) and the Phytochemistry of Artemisia Annua L. (Qinghao). Molecules. 2010; 15(11): 76037698

5. Kimbi HK, Ntoko M, Ntonifor NN, Lum E, Njunda AL, and Fon PN. Efficacy and Tolerability of Malartin and Sulphadoxine-Pyrimethamine Combination against Uncomplicated Falciparum Malaria in Dibanda, Southwest Cameroon. Journal of Tropical Medicine. 2012; 2012.

6. Percario S, Moreira DR, Gomes BAQ, et al. Oxidative Stress in Malaria. International Journal of Molecular Sciences. 2012; 13(12): 16346-16372.

7. Schmuck G, Roehrdanz E, Haynes RK, and Kahl R. Neurotoxic Mode of Action of Artemisinin. Antimicrobial Agents and Chemotherapy. 2002; 46(3); 821-827.

8. Rosenthal PJ. Artesunate for the Treatment of Severe Falciparum Malaria. The New England Journal of Medicine. 2008; 358: 1829-1836.

9. Winstanley P, Ward S, Snow R, and Breckenridge A. Therapy of Falciparum Malaria in Sub-Saharan Africa: from Molecule to Policy. Clinical Microbiology Reviews. 2004; 17(3): 612-637.

10. Woodrow CJ, Haynes RK and Krishna S. Artemisinins. Postgraduate Medical Journal. 2005; 81(952): 71-78.

11. Gupta S, Thapar MM, Wernsdorfer WH, and Bjorkman A. In vitro Interactions of Artemisinin with Atovaquone, Quinine and Mefloquine against Plasmodium falciparum. Antimicrobial Agents and Chemotherapy. 2002; 46(5): 1510-1515.
Plasmodium berghei (30)

Penelitian ini penggunaan terapi kombinasi Artemisin dengan ekstrak daun Moringa oleifera terbukti dapat lebih baik menurunkan derajat parasitemia, kadar MDA, dan jumlah pembuluh darah pada jaringan otak mencit model malaria yang di infeksi Plasmodium berghei dibandingkan dengan Artemisin monoterapi. Namun penelitian ini mempunyai keterbatasan karena belum menggunakan ekstrak Moringa oleifera monoterapi yang menggambarkan lebih baik efek skizontisida pada Moringa oleifera. Selain itu penelitian ini hanya mengukur kadar MDA yang hanya menggambarkan sebagian kecil kondisi radikal bebas di otak mencit yang di infeksi malaria, sehingga diperlukan pengukuran parameter lainnya yang berhubungan dengan radikal bebas, sehingga mampu didapatkan gambaran yang lebih baik tentang kondisi radikal bebas pada infeksi malaria.

12. Rathod PK, McErlean T, and Lee PC. Variations in Frequencies of Drug Resistance in Plasmodium falciparum. Proceedings of the National Academy of Sciences of the United States of America. 1997; 94(17): 9389-9393.

13. Fitri LE, Iskandar A, Permatasari N, Gunawan JA, dan Indrawan K. Efek Kombinasi Artemisinin dan NAC, Menurunkan Kadar Otak dan Paru Mencit yang Diinfeksi N-acetylcysteine Malondialdehyde Plasmodium Berghei. Jurnal Kedokteran Brawijaya. 2008; 24(2): 73-78.

14. Pari L, Karamac M, Kosinska A, Rybarczyk A, and Amarowicz R. Antioxidant Activity of the Crude Extracts of Drumstick Tree (Moringa oleifera Lam.) and Sweet Broomweed (Scoparia Dulcis L.) Leaves. Polish Journal of Food and Nutrition Sciences. 2007; 57(2): 203-208.

15. Patel JP, Gami B, and Patel K. Evaluation of in Vitro Schizonticidal Properties of Acetone Extract of Some Indian Medicinal Plants. Advances in Biological Research. 2010; 4(5): 253-258.

16. Ugwu OPC, Ndowoo OFC, Joshua PE, et al. AntiMalaria and Hematological Analyses of Ethanol Leaf Extract of Moringa oleifera on Malaria Infected Mice. International Journal of Pharmacy and Biological Science. 2013;3(1): 360-371.

17. Sardjono TW dan Fitri LE. Malaria, Mekanisme Terjadinya Penyakit dan Pedoman Penanganannya. Malang: Laboratorium Parasitologi FKUB; 2007.

18. Anonymous. Bioxytech ${ }^{\circledR}$ MDA-586 Assay Kit. Spectrophotometric Assay for Malondialdehyde. (Online). http://www.oxisresearch.com/ product_details.html?prodid=21044.

19. Al-Dissi AN, Haines DB, Singh B, and Kidney BA. Immunohistochemical Expression of Vascular Endothelial Growth Factor and Vascular Endothelial Growth Factor Receptor-2 in Canine Simple Mammary Gland Adenocarcinomas. Canadian Veterinary Journal. 2010; 51(10): 1109-1114.

20. Krishnegowda G, Hajjar AM, Zhu J, et al. Induction of Proinflammatory Responses in Macrophages by the Glycosylphosphatidylinositols of Plasmodium falciparum: Cell Signaling Receptors, Glycosylphosphatidylinositol (GPI) Structural 
Requirement, and Regulation of GPI Activity. The Journal of Biological Chemistry. 2005; 280(9): 86068616.

21. Kleinert $H$, Scwarz PM, and Forstermann U. Regulation of the Expression of Inducible Nitric Oxide Synthase. The Biological Chemistry. 2003; 384(10-11): 1343-1364.

22. Shabir G, Anwar F, Sultana B, et al. Antioxidant and Antimicobial Attributes and Phenolics of Different Solvent Extracts from Leaves, Flowers and Bark of Gold Mohar [Delonix regia (Bojer ex Hook.) Raf.]. Molecules. 2011; 16(9): 7302-7319.

23. Malaquarnera $\mathrm{L}$ and Musumeci $\mathrm{S}$. The Immune Response to Plasmodium falciparum Malaria. The Lancet Infectious Diseases. 2002; 2(8): 472-478.

24. Wresdiyati T. Imunohistochemical Study of OxygenFree Radical Scavenger-Copper, Zinc-Superoxide Dismutase (Cu,ZnSOD) in The Rats Liver Under Stress Condition. Biota. 2003; 8(3): 107-112.

25. Ogunro SP, Ogungbamigbe $O T$, Salawu $A A$, and Idogun SE. Erytrocyte Antioxidant Enymes and Lipid Peroxidation in Patient with Acute Attack of Plasmodium Falciparum. Oxidant and Antioxidant in Medical Science. 2012; 1(2): 111-118.

26. Raza A, Varshney SK, Shahid M, et al. Lipid
Peroxidation in Cerebral Malaria and Role of Antioxidants. Journal of Pharmary. New Delhi. 2013; 3(1): 15-18.

27. Luqman S, Srivastava S, Kumar R, Maurya AK, and Chandra, D. Research Article: Experimental Assessment Moringa oleifera Leaf and Fruit for It's Antistress, Antioxidant, and Scavenging Potential Using In Vitro and In Vivo Assays. Evidence-Based Complementary and Alternative Medicine. Evidencebased Complementary and Alternative Medicine. 2012; 2012.

28. Odunlade A, Ashade AA, Akinosola JP, Akindele S, and Adewole, AA. Antioxidant Evaluation of Moringa oleifera Therapy Combination in Mice with Plasmodium berghei Malaria. 5th World Congress on Biotechnology, Valencia Conference Centre. Valencia, June 25-27, 2004: p. 3-7.

29. Deininger MH, Winkler S, Kremsner PG, Meyermann R, and Schluesener HJ. Angiogenic Proteins in Brains of Patients Who Died with Cerebral Malaria. Journal of Neuroimmunology. 2003; 142(1-2): 101-111.

30. Octo R. Pengaruh Sari Buah Merah (Pandanus conoideus Lam.). Terhadap Gambaran Histopatologi Otak Mencit Jantan Strain BALB/C Yang Diinokulasi Plasmodium berghei. [Tesis]. Universitas Maranatha, Bandung. 2009. 